Hydrol. Earth Syst. Sci., 18, 1073-1087, 2014

www.hydrol-earth-syst-sci.net/18/1073/2014/

doi: 10.5194/hess-18-1073-2014

(C) Author(s) 2014. CC Attribution 3.0 License.

\title{
Dynamics of auto- and heterotrophic picoplankton and associated viruses in Lake Geneva
}

\author{
A. Parvathi ${ }^{1,2}$, X. Zhong ${ }^{2}$, A. S. Pradeep Ram ${ }^{3}$, and S. Jacquet ${ }^{2}$ \\ ${ }^{1}$ National Institute of Oceanography, Dr Salim Ali Road, P.O. Box 1913, 682018 Kochi, India \\ ${ }^{2}$ INRA - UMR042 CARRTEL, 75 Avenue de Corzent, 74203 Thonon-les-Bains cx, France \\ ${ }^{3}$ Laboratoire Microorganismes, Génome et Environnment, CNRS - UMR6023, Clermont Université, \\ Université Blaise Pascal, BP 80026, 63171 Aubière Cedex, France
}

Correspondence to: Stéphan Jacquet (stephan.jacquet@ thonon.inra.fr)

Received: 12 June 2013 - Published in Hydrol. Earth Syst. Sci. Discuss.: 4 July 2013

Revised: 4 February 2014 - Accepted: 10 February 2014 - Published: 19 March 2014

\begin{abstract}
Microbial dynamics have rarely been investigated in Lake Geneva, known as the largest lake in western Europe. From a 5-month survey, we report dynamic patterns of free-living virus, bacteria and small phytoplankton abundances in response to a variety of environmental parameters. For the first time, we fractionated the primary production to separate the contribution of different size-related biological compartments and measured both bacterial and viral production in addition to experiments conducted to quantify the virus-induced bacterial mortality. We observed marked seasonal and vertical variations in picocyanobacteria, bacteria and virus abundances and production. The contribution of picoplankton and nanoplankton production to the total primary production was high (reaching up to $76 \%$ of total primary production) in November and the spring-summer transition period, respectively. The impact of viral lysis on both bacteria and picocyanobacteria was significantly higher than grazing activities. Virus-induced picocyanobacterial mortality reached up to $66 \%$ of cell removal compared to virus induced (heterotrophic) bacterial mortality, which reached a maximum of $34 \%$ in July. Statistical analyzes revealed that temperature and top-down control by viruses are among important factors regulating the picocyanobacterial dynamics in this lake. More generally speaking, our results add to the growing evidence and accepted view nowadays that viruses are an important actor of freshwater microbial dynamics and more globally of the functioning of the microbial food webs.
\end{abstract}

\section{Introduction}

As is true for any ecosystem, Lake Geneva is changing continuously, posing challenges to ecologists (Anneville et al., 2013). Over the past few decades, water quality monitoring surveys have been performed under the authority of the International Commission for the Protection of Lake Geneva (see reports at http://www.cipel.org/sp/), in order to study the water quality, functioning and evolution of this ecosystem, which is connected to an important catchment area. The detailed analysis of the viral and microbial communities in Lake Geneva during periods of the year such as the springto-summer and the summer-to-fall transitions have not been provided yet. The interactions between these microorganisms and their environment within the food webs are, however, a key issue to study for a better understanding of Lake Geneva ecology.

Picoplankton is an integral component of the microbial community which seems to be ubiquitous in all seas and lakes (Azam et al., 1983; Callieri and Stockner, 2002). In aquatic microbial ecology, the term picoplankton traditionally refers to all cells which fall into the size class $0.2-3 \mu \mathrm{m}$; that includes picocyanobacteria, heterotrophic bacteria, archaea and small eukaryotic phototrophs referred to as picoeukaryotes (Li et al., 1983; Whitman et al., 1998; Worden and Not, 2008; Auguet et al., 2010). The ubiquitous distribution of the picophytoplankton (cyanobacteria and autotrophic picoeukaryotes) and their importance in terms of biomass and production make them a critical food web component and carbon cycling in a wide variety of aquatic environments 
(Worden et al., 2004). Compared to autotrophic picoplankton, heterotrophic bacteria contribute a larger percentage to total plankton biomass and play a central role in the transformation and mineralization of organic matter in the biosphere. These heterotrophs contribute largely to the cycling of carbon and nutrients in aquatic systems (Sarmiento and Gruber, 2006) and also form an important nutrient resource for higher trophic levels (i.e., the heterotrophic nanoflagellates, ciliates, metazooplankton).

Autochthonous and allochthonous factors can impact both auto- and heterotrophic organisms, affecting their distribution, structure, diversity as well as interactions among the organisms. The dynamics of picoplankton in aquatic ecosystems are not only controlled by abiotic factors (temperature, light, and nutrients), but also by biotic factors such as natural death, viral lysis, predation and parasitism. In recent years, top-down control of picoplankton populations has evoked much interests among microbial ecologists with the finding of large numbers of viruses $\left(10^{8}-10^{11} \mathrm{~L}^{-1}\right)$ in aquatic systems. Studies have now revealed that viral lysis can be a significant source of mortality, as important as bacterivory by protists (Fuhrman and Noble, 1995; Pradeep Ram et al., 2005; Personnic et al., 2009b). Through their lysis activity, viruses also play an important role in regulating carbon and nutrient fluxes, food web dynamics and microbial diversity in aquatic systems (Suttle, 2005; Jacquet et al., 2010; Breitbart, 2012).

The factors that influence viral abundance and dynamics in aquatic environments are complex and are found to vary with aquatic ecosystems (Clasen et al., 2008). Although a large majority of these studies have been focused on marine environments (Weinbauer and Suttle, 1997; Weinbauer, 2004), fewer investigations have been carried out in freshwater systems to study the influence of environmental factors on the dynamics of viral communities associated with autotrophic and heterotrophic picoplankton (Maranger and Bird, 1995; Clasen et al., 2008; Jacquet et al., 2010). Studies have shown that the viral abundance is influenced more by the bacterial abundance in marine environments and by chlorophyll $a$ concentration in nutrient-rich lakes (Pradeep Ram et al., 2010). A few studies in the lacustrine environments have included the influence of grazers on the picoplankton and bacterial abundances in studying viral dynamics (Personnic et al., 2009b; Berdjeb et al., 2011).

Lake Geneva is a mesotrophic peri-alpine lake where past studies have suggested that Synechococcus is the most predominant species in the autotrophic picoplankton (APP) (Duhamel et al., 2006; Personnic et al., 2009a). Lake Geneva has been poorly investigated in terms of microbial dynamics and diversity, and information on virus-bacteria, flagellatesbacteria and picocyanobacteria-ciliates interactions is still lacking for this lake (Duhamel et al., 2005; Personnic et al., 2009a, b). Our aim was to bring out an understanding about how various environmental and water quality parameters vary over a period of 5 months and how these changes may determine the abundance of autotrophic and heterotrophic plankton and associated viruses and to elucidate the type and extent of relationships of various physical, chemical and biological factors in determining the abundance of various autotrophic and heterotrophic planktonic groups in Lake Geneva. Recently by using a PCR-based molecular approach, we showed that Lake Geneva displays clear seasonal variations in the diversity of viruses (Parvathi et al., 2012). However, information regarding both the phytoplankton (in particular the picophytoplankton) dynamics and production and the dynamics and role of associated viruses is still lacking from this lake. Further, the influence of various chemical and physical parameters on viruses and different groups of plankton has not yet been well documented. Therefore, in the present study we proposed to highlight the seasonal and vertical variations in environmental and water quality parameters and resultant changes in picoplankton abundance, production and different viral parameters in relation to both biotic and abiotic factors in Lake Geneva over a 5-month period including summer and fall.

\section{Materials and methods}

\subsection{Study site and sampling strategy}

Lake Geneva, which lies at an altitude of $372 \mathrm{~m}$, is the largest lake in western Europe and forms the border between France and Switzerland at the north of the French Alps. The lake is $72 \mathrm{~km}$ long and $13 \mathrm{~km}$ wide with an area of $580 \mathrm{~km}^{2}$. Its catchment area is about $7419 \mathrm{~km}^{2}$, reaching a maximal altitude of $4634 \mathrm{~m}$ (the average altitude is $1670 \mathrm{~m}$ ), and at least 60 different tributaries aliment the lake (among which the Rhone River as the main one, with on average $180 \mathrm{~m}^{3} \mathrm{~s}^{-1}$ ). In terms of hydrology, annual rainfall has been about $1000 \mathrm{~mm}$ for the period 1981-2010. The water circulation of the lake has been clearly less studied (Lemmin et al., 1999; Ishiguro and Balvay, 2003). It is a meromictic lake, never covered by ice, with temperature ranging between 4 and $22^{\circ} \mathrm{C}$. It holds an approximate volume of $89 \times 10^{9} \mathrm{~m}^{3}$ for a maximum depth of $309 \mathrm{~m}$ (average depth is $152 \mathrm{~m}$ ), and this lake was reported as eutrophic during the 1970s. Later during the 1990s, following restoration programs, including measures to reduce phosphorus inputs, the lake changed to a mesotrophic state. In 2011, the lake had a total phosphorus content of $27 \mu \mathrm{gPL}^{-1}$ (Lazzarotto and Klein, 2012). In our study, samples were collected at the reference station (lat $46^{\circ} 27^{\prime} \mathrm{N}$, long $6^{\circ} 32^{\prime} \mathrm{E}$ ), corresponding to the deepest part of the lake at monthly or bimonthly intervals from July to November 2011. The summer period extended from the end of July to September, and autumn from October to November. The samples were collected at different depths $(2,7.5,10,15,20,25$, and $30 \mathrm{~m}$ ) using a Niskin water sampler in two $20 \mathrm{~L}$ polycarbonate containers and stored at ambient temperature, protected 
from light and heat, and brought to the laboratory within $3 \mathrm{~h}$ of collection.

\subsection{Environmental parameters and plankton analysis}

A multiparameter probe (CTD 90M, Sea and Sun Technology) was used to collect different parameters: temperature, light, conductivity, chlorophyll $a$ and oxygen profiles. Samples collected at discrete depths $(2.5,5,7.5,10,15$, 20,30 , and $50 \mathrm{~m}$ ) were analyzed for nutrients, namely nitrate $\left(\mathrm{N}-\mathrm{NO}_{3}\right)$, nitrite $\left(\mathrm{N}^{-\mathrm{NO}_{2}}\right)$, total nitrogen $\left(\mathrm{N}_{\text {tot }}\right)$, phosphate $\left(\mathrm{PO}_{4}\right)$, total phosphorous $\left(\mathrm{P}_{\text {tot }}\right)$ and silicate $\left(\mathrm{SiO}_{2}\right)$ using standard methods (Anneville et al., 2005). Raw water samples for the phytoplankton analysis were taken with a patented integrating instrument developed by Pelletier and Orand (1978) integrating the 0-18 m upper water layer and fixed with a few drops of Lugol's solution for phytoplankton and zooplankton analysis. For each sample, $25 \mathrm{~mL}$ was poured into an Utermöhl room (cylinder surmounting a blade with sediment chamber; Utermöhl, 1931) and left to form a deposit for at least $12 \mathrm{~h}$ away from light and heat. The qualitative and quantitative examination of the phytoplankton was carried out using inverted microscopy (Zeiss). For the zooplankton, vertical sampling from a depth of $50 \mathrm{~m}$ to the surface was carried out using a net of $212 \mu \mathrm{m}$ mesh size. The samples were fixed with formol $(5 \% \mathrm{v} / \mathrm{v})$. The enumeration of microcrustaceae presented here was achieved by means of a standard microscope (Olympus BX40) following Anneville et al. (2007).

\subsection{Flow cytometry analysis}

Virus-like particles (VLPs) from discrete depths were counted using a FACSCalibur flow cytometer (FCM) (Becton Dickinson) equipped with an air-cooled laser providing $15 \mathrm{~mW}$ at $488 \mathrm{~nm}$. Samples were fixed with glutaraldehyde ( $0.5 \%$ final concentration, grade I, Merck) for $30 \mathrm{~min}$, then diluted in $0.02 \mu \mathrm{m}$ filtered Tris-EDTA buffer (referred to as TE, $0.1 \mathrm{mM}$ Tris-HCL and $1 \mathrm{mM}$ EDTA, $\mathrm{pH} 8$ ), and incubated with SYBR Green I (at a final $10^{-4}$ dilution of the commercial stock solution; Molecular Probes), for $5 \mathrm{~min}$ at ambient temperature in the dark. At last, the sample was incubated for $10 \mathrm{~min}$ at $75^{\circ} \mathrm{C}$, and for another $5 \mathrm{~min}$ at room temperature prior to FCM analysis (Personnic et al., 2009a). FCM discriminated at least 3 subgroups of viruses, designated as VLP1, VLP2 and VLP3 (virus-like particles, group 1, 2 and 3) (Jacquet et al., 2010), but only VLP1 and VLP2 could be observed throughout the period of analysis and were shown thereafter. The analysis for determining heterotrophic bacterial abundance from different depths was performed as for the viruses but without heating at $75^{\circ} \mathrm{C}$ and by using $<0.02 \mu \mathrm{m}$ filtered lake water instead of TE (details can be found in Jacquet et al., 2013). The picocyanobacteria and other smaller phytoplankters were analyzed without fixing or staining, but by using their natural autofluorescence.
During previous experiments or surveys in peri-alpine lakes (e.g., Annecy, Bourget and Geneva), some picocyanobacteria were sorted with flow cytometry and cultured, and both genetic affiliation and size were analyzed in order to confirm their identity. All cultured strains isolated so far with typical phycoerythrin-rich (PE) picocyanobacteria FCM signatures belong to Synechococcus-like populations and these PE-rich picocyanobacteria for the French sub-Alpine lakes vary in size between 1.5 and $2.5 \mu \mathrm{m}$ (Jacquet, unpublished). Analysis was made on samples to which a suspension of $1 \mu \mathrm{m}$ beads had been added (Molecular Probes).

\subsection{Fractionated primary production}

Size-fractionated primary production at five discrete depths $(2.5,7.5,10,15$ and $20 \mathrm{~m})$ was determined by in situ incubations with the isotope ${ }^{14} \mathrm{C}$. $<200 \mu \mathrm{m}$ water samples from each depth were filled into three $250 \mathrm{~mL}$ glass bottles (two "light" and one "dark" bottle). These bottles were inoculated with $1 \mathrm{ml}$ of radiolabeled $\mathrm{NaH}^{14} \mathrm{CO}_{3}\left(5 \mu \mathrm{Ci} \mathrm{mL}^{-1}\right)$ and subsequently incubated for $5 \mathrm{~h}$ at respective depths where the water was sampled. At the end of the incubation, samples were sequentially filtered through $20 \mu \mathrm{m}$ nylon mesh and 3.0 and $0.2 \mu \mathrm{m}$ polycarbonate filters. The phytoplankton cells concentrated in the $20 \mu \mathrm{m}$ mesh were washed with filtered lake water and again concentrated on $0.7 \mu \mathrm{m} \mathrm{GF} / \mathrm{F}$ filters. This corresponded to the microphytoplankton fraction, whereas the 3.0 and $0.2 \mu \mathrm{m}$ represented the nano- and picophytoplankton fractions, respectively. The filters were used for subsequent analysis after removing excess dissolved inorganic carbon $\left(\mathrm{DI}^{14} \mathrm{C}\right)$ by exposing it to concentrated hydrochloric acid fumes for one minute. The filters were then placed in scintillation vials and a $5 \mathrm{~mL}$ scintillation cocktail was added. Radioactivity was measured using a liquid scintillation counter (Beckman Coulter, USA). Production rate was calculated based on the photoperiod of each day and expressed as $\mu \mathrm{gCL}^{-1} \mathrm{~d}^{-1}$. Other details can be found elsewhere (Anneville et al., 2002; Tadonléké, 2010).

\subsection{Bacterial and viral production}

Water samples collected in polycarbonate bottles (in triplicates) were stored in ice and transported to the laboratory. Bacterial production was determined by incorporation of the nucleoside ${ }^{3} \mathrm{H}$ Thymidine into bacterial DNA (Jugnia et al., 1999) on the integrated $0-18 \mathrm{~m}$ water samples. Briefly, a $30 \mathrm{~mL}$ water sample (in triplicates) along with trichloroacetic acid (TCA) killed control ( $1 \%$ final concentration) was incubated with ${ }^{3} \mathrm{H}$ Thymidine $\left({ }^{3} \mathrm{H} \mathrm{TdR}\right)$ at a final concentration of $10 \mathrm{nM}$ in the dark for $1 \mathrm{~h}$ at ambient temperature in the laboratory. TdR incorporation was stopped by adding $1 \%$ TCA. The samples were filtered through $0.22 \mu \mathrm{m}$ (Millipore, USA) membrane filter, extracted in cold $5 \%$ TCA and rinsed with $80 \%$ ethanol. The dried filters were placed in scintillation vials and $0.5 \mathrm{~mL}$ of ethyl acetate was added to dissolve 
the filter. A $5 \mathrm{~mL}$ scintillation cocktail was added and the radioactivity was measured using liquid scintillation counter (LS 6500 Scintillation Counter, Beckman Coulter, USA). The disintegration values per minute (dpm) after correcting for blank were converted to moles $\mathrm{TdR}$ of bacterial cells $\left(2 \times 10^{18}\right.$ cells mol $\left.^{-1}\right)$ and bacterial carbon $\left(20 \mathrm{fg} \mathrm{C} \mathrm{cell}^{-1}\right)$.

Viral production was estimated by the virus reduction method (Wilhelm et al., 2002), similar to a previous study conducted at a peri-Alpine lake by Thomas et al. (2011). Briefly, a $100 \mathrm{~mL}$ water sample was diluted with 3 volumes of ultrafiltered sample $(<0.02 \mu \mathrm{m}$, free of viruses) to reduce the number of free viruses in the sample significantly. This was divided into three replicates and samples were incubated in the dark for $24 \mathrm{~h}$. Subsamples were drawn at 2-hourly intervals to monitor the abundance of bacteria and viruses. The bacterial and viral abundances were determined using flow cytometry as described above.

\subsection{Transmission electronic microscopy (TEM) analysis}

Viral lytic infections were inferred from the percentage of visibly infected 8 cells (FVIC) according to SimeNgando et al. (1996). Bacterial cells contained in milliliters of glutaraldehyde-fixed samples (1\% final concentration), which were stored at $4{ }^{\circ} \mathrm{C}$, were harvested by ultracentrifugation onto 400 mesh NI electron microscope grids with carbon-coated Formvar film, by using a Beckman Coulter SW40 Ti swing-out rotor run at $70000 \times g$ for $20 \mathrm{~min}$ at $4{ }^{\circ} \mathrm{C}$. Each grid was stained at room temperature (ca. $20^{\circ} \mathrm{C}$ ) for $30 \mathrm{~s}$ with uranyl acetate $(2 \% \mathrm{wt} / \mathrm{wt})$, rinsed twice with $0.02 \mu \mathrm{m}$ filtered distilled water and dried on a filter paper. Grids were then examined using a JEOL $1200 \mathrm{E} \times$ TEM operated at $80 \mathrm{kV}$ at a magnification of $\times 100000$. At least 600-800 prokaryotic cells per sample were examined to determine the frequency of visibly infected cells (FVIC). Cells were scored as infected if they contained five or more intracellular viruses. For each sample, the mean burst size (viruses bacteria ${ }^{-1}$ ) was estimated from the number of viruses in visibly infected cells. Because mature phages are visible only late in the infection cycle, FVIC counts were converted to the frequency of infected cells (FIC) using the equation $\mathrm{FIC}=9.524 \times \mathrm{FVIC}-3.256$ (Weinbauer et al., 2002). The FIC was then converted to viral-induced bacterial mortality (VIBM, as a percentage per generation) according to Binder (1999) using the equation $\mathrm{VIBM}=(\mathrm{FIC}+0.6 \times \mathrm{FIC} 2) /(1-1.2 \times \mathrm{FIC})$.

\subsection{Dilution experiments and viral parameters}

The modified dilution approach was used to determine the grazing and viral-induced mortality on picoplankton and bacteria (Evans et al., 2003) as previously done by Personnic et al. (2009b) and Thomas et al. (2011). In this method, parallel dilution series (70, 40 and $20 \%$ ) of natural lake water was performed with $0.2 \mu \mathrm{m}$ filtered sample to obtain the grazing rate and with $30 \mathrm{kDa}$ filtered sample to obtain grazing and viral lysis rates. Percentages of grazing and viral mortality were determined from the difference between the two dilution series, provided that the regression slopes were significant (Kimmance et al., 2007). Viral mortality rates $\left(\mathrm{d}^{-1}\right)$ were also calculated as the ratio of viral production and burst size. The lytic mortality rate was calculated from viral lysis rate and bacterial abundance.

\subsection{Statistical analysis}

The statistical analysis was carried out for the monthly data for the abundance of heterotrophic bacteria, picocyanobacteria, other phytoplankton, VLP1, VLP2, total VLP and other physicochemical parameters. The dependent variables were the abundance of bacteria, picocyanobacteria, other phytoplankton, VLP1, VLP2 and VLP. The independent variables influencing dependent variables have been considered as explanatory variables (i.e., temperature, $\mathrm{pH}$, turbidity, $\mathrm{PO}_{4}$, $\mathrm{P}_{\text {tot }}, \mathrm{P}_{\text {part }}, \mathrm{Mg}$, COT, $\mathrm{Na}, \mathrm{Ca}, \mathrm{NH}_{4}, \mathrm{Cl}, \mathrm{SO}_{4}, \mathrm{Chl} a$, dissolved oxygen, $\mathrm{N}_{\text {tot }}, \mathrm{NO}_{3}-\mathrm{N}, \mathrm{NO}_{2}-\mathrm{N}, \mathrm{SiO}_{2}-\mathrm{Si}$ ). The presence of autocorrelation was checked using the PAST software (PAST version 2.14), which revealed correlations which were not significant. Also, explanatory variables were found to be highly correlated, indicating the presence of multicollinearity. Hence, an alternative method of estimation, the principal component regression, was used to examine the factors that influence the abundances of picoplankton, bacteria and viruses. The principle components were obtained by eigenvalue decomposition of the covariance or correlation matrix of the explanatory variables. For the analysis of variations in VLPs, biological factors such as the bacterial, picocyanobacterial and the other phytoplankton abundances were included as independent variables in factor analysis.

\section{Results}

\subsection{Environmental factors}

The mean along with standard deviation values of all the environmental parameters are provided in Table 1, while the dynamics and/or distribution of some of them can be appreciated in Fig. 1. Briefly, the average water temperature during the study period was $14.0 \pm 5.2^{\circ} \mathrm{C}$, with minimum and maximum values of $6.2^{\circ} \mathrm{C}$ (November) and $21.5^{\circ} \mathrm{C}$ (August), respectively. Vertical profiles showed water temperature to decrease rapidly from surface $\left(19.6^{\circ} \mathrm{C}\right)$ to $30 \mathrm{~m}\left(6.9^{\circ} \mathrm{C}\right)$. The vertical stratification was well marked in summer. In the air, the temperature was relatively high during summer, reaching $25^{\circ} \mathrm{C}$ with fluctuations between 15 and $25^{\circ} \mathrm{C}$. After August, the air temperature decreased significantly month after month down to $5^{\circ} \mathrm{C}$ in November, but the decrease was clearly lower in the upper lit layer of the lake itself. Paralleling the decrease of air temperature, the same trend was observed for the photosynthetic active radiation. The dissolved 

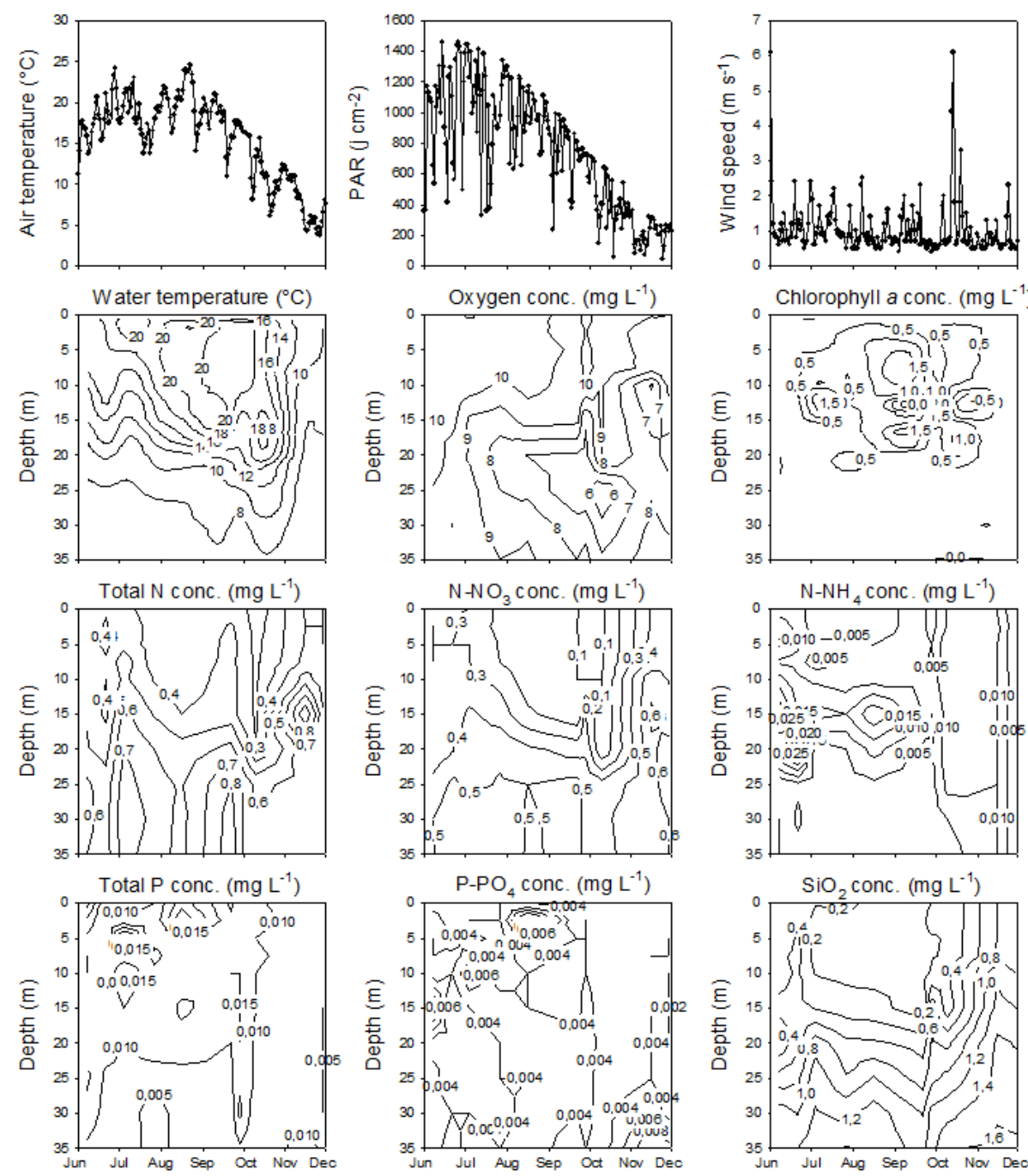

2011

Fig. 1. Time series obtained for the main environmental parameters from June to December 2011. The interpolation between the data was generated automatically by SigmaPlot 12.0 .

oxygen concentration varied between 5.2 and $10.9 \mathrm{mg} \mathrm{L}^{-1}$. The highest values were recorded in the $0-10 \mathrm{~m}$ surface layer, and values decreased only slightly from summer to fall. During the study period, the concentrations of TP and TN varied by a factor of 15 and 8 , respectively. Both nitrogen and phosphorus values varied significantly $(p<0.05)$ with respect to months and depths. Such variations were mainly due to $\mathrm{NO}_{3}$ for TN. Chlorophyll $a$ concentrations ranged from 0.8 to $6.8 \mu \mathrm{g} \mathrm{L}{ }^{-1}$ with the highest and lowest values in July at 7.5 and $30 \mathrm{~m}$ depths, respectively. This parameter clearly revealed that the phytoplankton was not distributed homogeneously through the water column and that it was mainly concentrated at $0-20 \mathrm{~m}$. As a matter of proof, water transparency varied between $4.5 \mathrm{~m}$ (at the end of July) and $11 \mathrm{~m}$ (mid-November) and the estimated euphotic zone thus varied between 11 and $28 \mathrm{~m}$.

\subsection{Abundances of heterotrophic bacteria, picocyanobacteria and other phytoplankton}

The heterotrophic bacterial population showed strong month-to-month and vertical variability, with maximum abundance $\left(5.76 \times 10^{6}\right.$ cells mL $\left.\mathrm{mL}^{-1}\right)$ observed in August at $10 \mathrm{~m}$ (Table 1). Bacterial abundance varied up to 5and 11-fold with month and depth, respectively. Similarly, the picocyanobacterial abundance was the highest

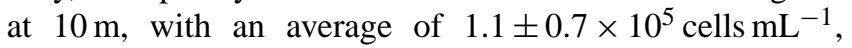
and the lowest at $30 \mathrm{~m}\left(2.2 \pm 1.4 \times 10^{3}\right.$ cells $\left.\mathrm{mL}^{-1}\right)$. The picocyanobacterial abundance maximum was recorded in August $\left(1.9 \times 10^{5}\right.$ cells $\left.\mathrm{mL}^{-1}\right)$ and minimum in November $\left(2.1 \times 10^{2}\right.$ cells mL $\left.\mathrm{m}^{-1}\right)$. Like bacterial and picocyanobacterial abundances, other FCM phytoplanktonic groups considered all together also displayed vertical 
Table 1. Minimum, maximum, mean and standard deviation values for all the variables measured in Lake Geneva in this study from July to November 2011. Abbreviations are mentioned in the text.

\begin{tabular}{|c|c|c|c|c|}
\hline Variables & Min & Max & Mean & SD \\
\hline Bacteria (cells $\mathrm{mL}^{-1}$ ) & $5.27 \times 10^{5}$ & $5.76 \times 10^{6}$ & $2.15 \times 10^{6}$ & $1.33 \times 10^{6}$ \\
\hline Picocyanobacteria (cells $\mathrm{mL}^{-1}$ ) & $2.11 \times 10^{2}$ & $1.94 \times 10^{5}$ & $5.72 \times 10^{4}$ & $5.82 \times 10^{4}$ \\
\hline Other phytoplankton (cells $\mathrm{mL}^{-1}$ ) & $1.48 \times 10^{1}$ & $3.21 \times 10^{4}$ & $4.05 \times 10^{3}$ & $7.64 \times 10^{3}$ \\
\hline VLP1 $\mathrm{mL}^{-1}$ & $2.92 \times 10^{7}$ & $1.21 \times 10^{8}$ & $7.16 \times 10^{7}$ & $2.92 \times 10^{7}$ \\
\hline VLP2 $\mathrm{mL}^{-1}$ & $4.83 \times 10^{5}$ & $1.30 \times 10^{7}$ & $5.25 \times 10^{6}$ & $3.41 \times 10^{6}$ \\
\hline VLP $\mathrm{mL}^{-1}$ & $3.06 \times 10^{7}$ & $1.29 \times 10^{8}$ & $7.69 \times 10^{7}$ & $3.23 \times 10^{7}$ \\
\hline VPR & 13.18 & 170.35 & 36.5 & 25.4 \\
\hline Temperature $\left({ }^{\circ} \mathrm{C}\right)$ & 6.22 & 21.53 & 14.0 & 5.15 \\
\hline Turbidity (FTU) & 0.71 & 2.01 & 1.16 & 0.30 \\
\hline $\mathrm{PAH}\left(\mu \mathrm{g} \mathrm{L}^{-1}\right)$ & 23 & 35 & 28.5 & 3.84 \\
\hline $\mathrm{PC}\left(\mu \mathrm{g} \mathrm{L}^{-1}\right)$ & 0.14 & 1.48 & 0.66 & 0.417 \\
\hline $\mathrm{pH}$ & 7.71 & 8.73 & 8.14 & 0.34 \\
\hline Par_w $(\mu \mathrm{E})$ & 0.58 & 730.2 & 92.8 & 164 \\
\hline $\mathrm{O}_{2}\left(\mu \mathrm{g} \mathrm{L}^{-1}\right)$ & 5.19 & 10.92 & 8.69 & 1.43 \\
\hline $\mathrm{NO}_{2}\left(\mu \mathrm{L} \mathrm{L}^{-1}\right)$ & 0.0 & 11.0 & 3.0 & 2.0 \\
\hline $\mathrm{PO}_{4}\left(\mu \mathrm{g} \mathrm{L}^{-1}\right)$ & 2.0 & 14 & 4.0 & 1.9 \\
\hline$P_{\text {part }}\left(\mu g \mathrm{~L}^{-1}\right)$ & 1.0 & 11.2 & 4.0 & 2.0 \\
\hline $\operatorname{COT}\left(\mathrm{mgC} \mathrm{L}^{-1}\right)$ & 0.23 & 1.61 & 1.05 & 0.23 \\
\hline $\mathrm{NO}_{3}\left(\mu \mathrm{g} \mathrm{L}^{-1}\right)$ & 80 & 610 & 340 & 187 \\
\hline $\mathrm{SiO}_{2}\left(\mu \mathrm{g} \mathrm{L}^{-1}\right)$ & 9.0 & 159 & 63.2 & 48.4 \\
\hline $\mathrm{P}_{\text {tot }}\left(\mu \mathrm{gPL}^{-1}\right)$ & 2.0 & 29.0 & 10 & 4.0 \\
\hline $\mathrm{NH}_{4}\left(\mu \mathrm{g} \mathrm{L}^{-1}\right)$ & 1.0 & 24.0 & 8.0 & 5.0 \\
\hline $\mathrm{N}_{\text {tot }}\left(\mu \mathrm{gNL}^{-1}\right)$ & 170 & 980 & 529 & 173 \\
\hline $\mathrm{SO}_{4}\left(\mathrm{mg} \mathrm{L}^{-1}\right)$ & 0.67 & 49.54 & 48.4 & 0.674 \\
\hline TAC $\left(\operatorname{meg~L}^{-1}\right)$ & 0.13 & 1.79 & 1.61 & 0.135 \\
\hline CHLA & 0.80 & 6.778 & 3.62 & 1.48 \\
\hline Microplankton production $\left(\mathrm{mgC} \mathrm{m}^{-3} \mathrm{~h}^{-1}\right)$ & 0.0025 & 5.30 & 1.41 & 1.62 \\
\hline Nanoplankton production $\left(\mathrm{mgC} \mathrm{m}^{-3} \mathrm{~h}^{-1}\right)$ & 0.0076 & 2.41 & 0.68 & 0.74 \\
\hline Picoplankton production $\left(\mathrm{mgC} \mathrm{m}^{-3} \mathrm{~h}^{-1}\right)$ & 0.05 & 4.40 & 1.55 & 1.38 \\
\hline
\end{tabular}

variations, with the highest concentrations observed at $7.5 \mathrm{~m}$ $\left(8.0 \pm 1.45 \times 10^{3}\right.$ cells $\left.^{-1}\right)$ in August and the lowest at $30 \mathrm{~m}\left(3.6 \pm 2.1 \times 10^{2}\right.$ cells $\left.\mathrm{mL}^{-1}\right)$ in November (Fig. 2).

\subsection{Virus-like particle abundances and lytic infection rates}

Maximum abundances of the virus-like particles (VLPs) were observed at $2.5 \mathrm{~m}\left(11.0 \pm 3.1 \times 10^{7}\right.$ particles $\left.\mathrm{mL}^{-1}\right)$ and the minimum at $30 \mathrm{~m}\left(4.4 \pm 0.74 \times 10^{7}\right.$ particles $\left.\mathrm{mL}^{-1}\right)$. Highest and lowest VLP abundances were observed in September $\left(1.3 \times 10^{8}\right.$ particles $\left.\mathrm{mL}^{-1}\right)$ and November $\left(3.1 \times 10^{7}\right.$ particles $\left.\mathrm{mL}^{-1}\right)$, respectively (Fig. 2). VLPs could be discriminated into two major groups, referred to as VLP1 and VLP2. Average VLP1 and VLP2 abundances were $7.2 \pm 2.9 \times 10^{7}$ particles $\mathrm{mL}^{-1}$ and $0.53 \pm 0.34 \times 10^{7}$ particles $\mathrm{mL}^{-1}$, respectively. The highest and lowest VLP1 and VLP2 abundances were $1.2 \times 10^{8}$ and $2.9 \times 10^{7}$ particles $\mathrm{mL}^{-1}$ and $1.3 \times 10^{7}$ and $4.8 \times 10^{5}$ particles $\mathrm{mL}^{-1}$, respectively, and they were both measured at 2.5 and $30 \mathrm{~m}$ depth. The virus-to-bacteria ratio was highest at $20 \mathrm{~m}$ depth $(56.6 \pm 5.6)$ and lowest at $10 \mathrm{~m}(27.6 \pm 12.2)$. The highest (170) and lowest (13.8) ratios were observed in July at different depths.

TEM analysis revealed that phages were mainly associated with oval and short rod morphotypes with an occurrence of $28 \%$, followed by thin rods $(25 \%)$ and cocci $(19 \%)$. The burst size of these morphotypes was on average 46 for oval morphotypes and less than 15 for the short rods. The burst size ranged from 15 to 132 in July, whereas the range was 21 to 35 in November. The average burst size ranged from 28 to 44 (mean $=32.6$, Table 2). The frequency of virus-infected cells ranged from $1.1 \%$ in November to $2.7 \%$ in July. Similarly the FIC was relatively low in November $(7.2 \%)$ and high in July $(22.5 \%)$. The virus-induced bacterial mortality was calculated to vary between $8.2 \%$ (November) and $34.9 \%$ (July), and there was a clear trend of decreased mortality from early summer to the end of fall (Fig. 3a).

Virus-induced mortality on picocyanobacteria, assessed using the modified dilution method, was also found to be 

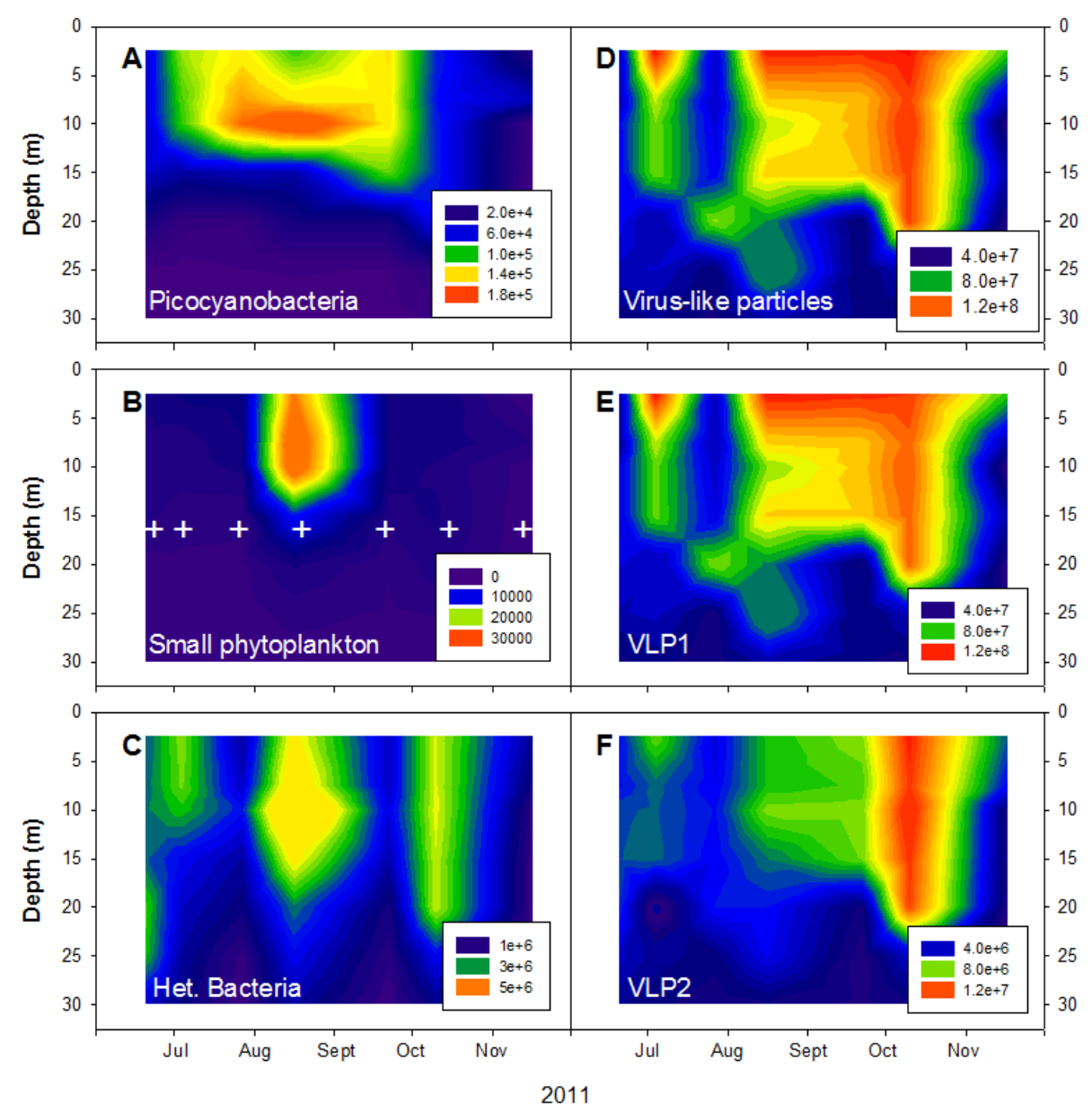

Fig. 2. Vertical distribution of picocyanobacteria (A), small phytoplankton populations (B), heterotrophic bacteria (C), total virus-like particles (D), VLP1 (E) and VLP2 (F) from July to November 2011 using flow cytometry. The white crosses in (B) refer to sampling dates. The interpolation between the data was generated automatically by SigmaPlot 12.0.

relatively high in summer (reaching $66 \%$ in August), while it could be insignificant at other periods, i.e., in November (Table 2). Comparatively, the virus-mediated bacterial mortality ranged from $18.3 \%$ (August) to $33.5 \%$ (July), and no trend was recorded as for TEM-estimated values (Fig. 3b). The grazing impact varied also a lot during the period of study (from 0 to $50 \%$ ), and it was globally lower than the viral impact for both the picocyanobacteria and the heterotrophic bacteria.

\subsection{Bacterial and viral production}

Bacterial production (BP) ranged from 9.1 to $36.9 \mu \mathrm{gCL}^{-1} \mathrm{~d}^{-1}$. The lowest $\mathrm{BP}$ was measured in September and the highest in July. The BP values slowly recovered during October-November, reaching a value of $15.5 \mu \mathrm{gCL}^{-1} \mathrm{~d}^{-1}$ (Fig. 4). The lowest viral production rate was found to be $1.24 \times 10^{7}$ particles $\mathrm{mL}^{-1} \mathrm{~d}^{-1}$ in July. Thereafter it increased from August to October, reaching up to $6.28 \times 10^{8}$ particles $\mathrm{mL}^{-1} \mathrm{~d}^{-1}$ in
October. Viral production decreased to approximately $5.1 \times 10^{8}$ particles $\mathrm{mL}^{-1} \mathrm{~d}^{-1}$ in November (Fig. 4).

\subsection{Size-fractionated primary production}

Primary production measured at 5 different depths between 2.5 and $20 \mathrm{~m}$ revealed marked seasonal and depthwise variations with all possible contributions of micro-, nano- and picoplankton to the total primary production. The total primary production maximum was estimated at $7.5 \mathrm{~m}$ depth in summer and at $2.5 \mathrm{~m}$ in fall. A maximum production rate of $18.5 \mathrm{mgC} \mathrm{m}^{-3} \mathrm{~h}^{-1}$ was reported at $7.5 \mathrm{~m}$ in August. With $6.6 \mathrm{mgC} \mathrm{m}^{-3} \mathrm{~h}^{-1}$ at $2.5 \mathrm{~m}$, November was the least productive month. The production rates decreased rapidly below $10 \mathrm{~m}$ depth. The picophytoplanktonic contribution was relatively high in October and November (Fig. 5), reaching up to $76 \%$, while it was only $33 \%$ in August. The depth at which the maximum picophytoplankton contribution was reported was $15 \mathrm{~m}$ throughout the sampling period. 
Table 2. Mean values for the frequency of virus-infected cells (FVIC), frequency of infected cells (FIC), virus-induced bacterial mortality (VIBM) and average burst size (BS) as estimated using transmission electron microscopy. PCGM refers to picocyanobacterial mortality due to grazing, while PCVM refers to the virus-mediated mortality of this community. BGM and BVM are as above but for the heterotrophic bacteria.

\begin{tabular}{|c|c|c|c|c|c|c|c|c|}
\hline \multirow[t]{2}{*}{ Sample } & \multicolumn{4}{|c|}{ TEM analysis } & \multicolumn{4}{|c|}{ Dilution experiments } \\
\hline & FVIC & FIC & VIBM & $\mathrm{BS}$ & $\begin{array}{l}\text { PCGM } \\
(\%)\end{array}$ & $\begin{array}{l}\text { PCVM } \\
(\%)\end{array}$ & $\begin{array}{l}\text { BGM } \\
(\%)\end{array}$ & $\begin{array}{l}\text { BVM } \\
(\%)\end{array}$ \\
\hline 4 Jul & $2.7 \pm 0.1$ & $22.5 \pm 2.7$ & $34.9 \pm 11.2$ & $41 \pm 4$ & $6.8 \pm 5.6$ & $23 \pm 8.2$ & $17.4 \pm 6.8$ & $19.9 \pm 8.1$ \\
\hline $27 \mathrm{Jul}$ & $2.1 \pm 0.3$ & $16.7 \pm 8.7$ & $23.1 \pm 5.7$ & $30 \pm 11$ & $12.1 \pm 10.2$ & $16.2 \pm 12.4$ & $28.9 \pm 13.7$ & $33.5 \pm 15.4$ \\
\hline 16 Aug & $1.4 \pm 0.6$ & $10.1 \pm 2.4$ & $12.2 \pm 3.4$ & $32 \pm 7$ & $50.2 \pm 23.8$ & $66 \pm 31.7$ & NS & $18.3 \pm 9.3$ \\
\hline $22 \mathrm{Sep}$ & $1.7 \pm 0.2$ & $12.9 \pm 4.1$ & $16.5 \pm 2.6$ & $44 \pm 14$ & NS & $35.7 \pm 11.6$ & $11.6 \pm 3.7$ & $19.8 \pm 8.5$ \\
\hline $10 \mathrm{Oct}$ & $1.2 \pm 0.1$ & $8.2 \pm 2.1$ & $9.5 \pm 3.3$ & $28 \pm 8$ & NS & $19.1 \pm 6.9$ & $18.1 \pm 5.9$ & $23.5 \pm 13.9$ \\
\hline $17 \mathrm{Nov}$ & $1.1 \pm 0.2$ & $7.2 \pm 3.1$ & $8.2 \pm 1.9$ & $28 \pm 6$ & $16.9 \pm 9.5$ & NS & $11 \pm 4.6$ & $21.1 \pm 10.8$ \\
\hline
\end{tabular}
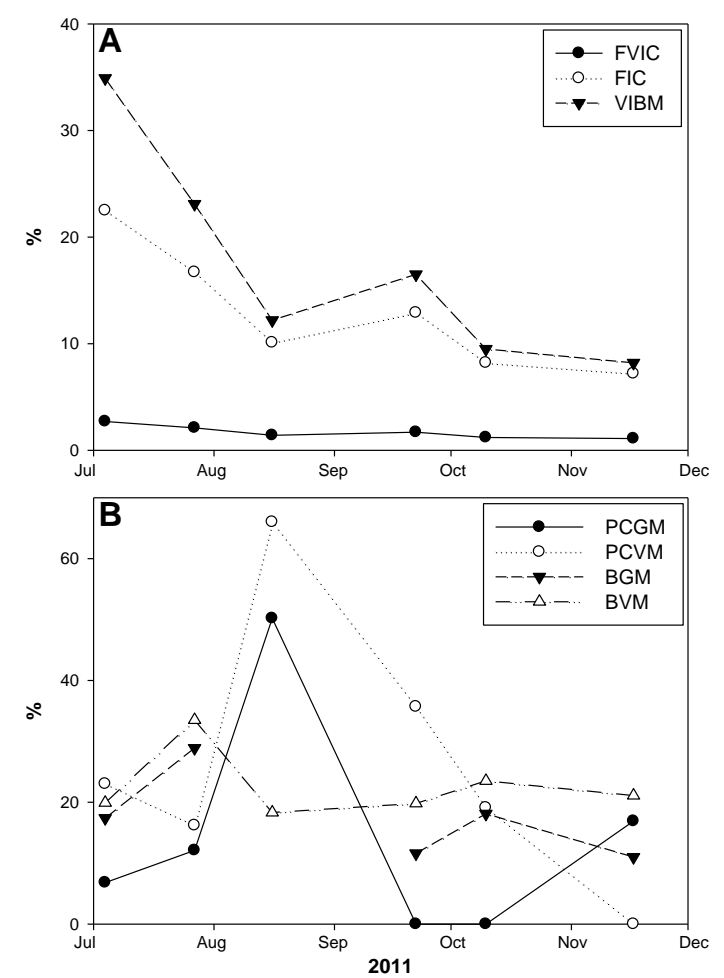

Fig. 3. Patterns of the frequency of virus-infected bacterial cells (FVIC), the frequency of infected bacterial cells (FIC) as estimated using transmission electron microscopy and the virus-induced bacterial mortality (VIBM) (A). Grazing mortality and viral lysis on picocyanobacteria (PCGM and PCVM, respectively) and on heterotrophic bacteria (BGM and BVM) estimated using the modified dilution technique (B).

\subsection{Statistical analysis}

The various environmental and biological factors showed significant seasonal variations. Summer months behaved differently with complex interactions between biological variables and physicochemical parameters. The bacterial

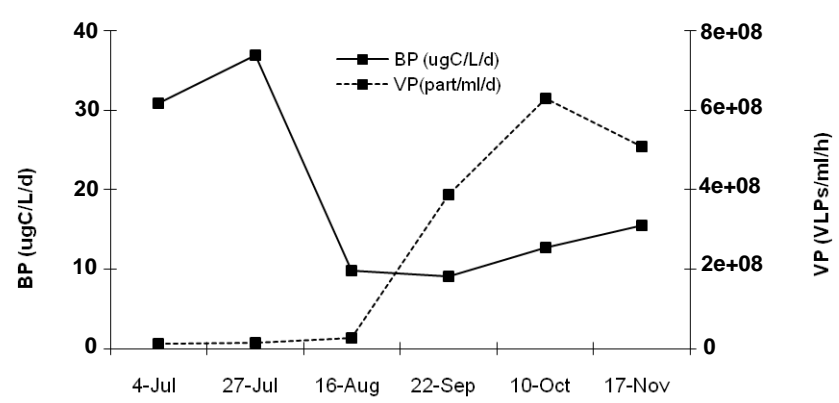

Fig. 4. Bacterial production (BP) and viral production (VP) measured from July to November 2011.

abundance was significantly correlated with picocyanobacteria, while picocyanobacteria were positively correlated with temperature, $\mathrm{pH}$ and $\mathrm{O}_{2}$, and negatively with $\mathrm{NO}_{3}, \mathrm{SiO}_{2}$ and total phosphorus. In summer, VLP1 did not show any correlation with any of the biological factors including the bacterial abundance, but had significant correlations with physicochemical factors like $\mathrm{pH}$ and total phosphorus and negative correlation with $\mathrm{NO}_{3}, \mathrm{SiO}_{2}$, total phosphorus and total nitrogen. VLP2 on the other hand displayed a significant positive correlation with picocyanobacteria and other phytoplankton. At first sight, temperature seems to be the most determining factor for planktonic abundance when compared to phosphorus. But over the months, the relationships were more complex with significant correlations between important measured biotic and abiotic factors, except for Chl $a$ (Table 3).

A principal component regression analysis was then performed to examine the environmental factors determining the dynamics of different planktonic communities in the take. The two main factors (axes) explained more than $70 \%$ of the total variance. Temperature and $\mathrm{pH}$ were important significant factors influencing the abundance not only of bacteria and picocyanobacteria but also of the primary production. For bacteria, factor 1 contributed to an eigenvalue of 4.34 , which included temperature (0.87), $\mathrm{pH}(0.94), \mathrm{NO}_{3}(-0.87)$, $\mathrm{SiO}_{2}(-0.93)$ and $\mathrm{P}_{\text {tot }}(0.70)$. For the picocyanobacteria, 
Table 3. Results of Pearson's correlation analysis to test for empirical correspondence among estimated variables. Abbreviations are explained in the main text. Significant correlations are in bold at $P<0.01$ at $n=42$.

\begin{tabular}{|c|c|c|c|c|c|c|c|c|c|c|c|c|}
\hline & Bact & $\mathrm{PC}$ & PP & VLP1 & VLP2 & VLP & Temp & $\mathrm{NO}_{3}$ & $\mathrm{SiO}_{2}$ & $\mathrm{P}_{\text {tot }}$ & $\mathrm{N}_{\text {tot }}$ & $\mathrm{pH}$ \\
\hline PC & 0.78 & & & & & & & & & & & \\
\hline PP & 0.79 & 0.82 & & & & & & & & & & \\
\hline VLP1 & 0.83 & 0.74 & 0.65 & & & & & & & & & \\
\hline VLP2 & 0.79 & 0.81 & 0.66 & 0.88 & & & & & & & & \\
\hline VLP & 0.83 & 0.75 & 0.66 & 0.99 & 0.90 & & & & & & & \\
\hline Temp & 0.56 & 0.79 & 0.60 & 0.61 & 0.67 & 0.63 & & & & & & \\
\hline $\mathrm{NO}_{3}$ & -0.78 & -0.88 & -0.76 & -0.81 & $-\mathbf{0 . 8 3}$ & -0.82 & -0.77 & & & & & \\
\hline $\mathrm{SiO}_{2}$ & -0.72 & -0.94 & -0.80 & -0.73 & -0.75 & -0.74 & -0.79 & 0.86 & & & & \\
\hline$P_{\text {tot }}$ & 0.62 & 0.54 & 0.60 & 0.57 & 0.42 & 0.56 & 0.44 & -0.51 & -0.61 & & & \\
\hline $\mathrm{N}_{\text {tot }}$ & -0.77 & -0.78 & -0.66 & -0.70 & -0.78 & -0.72 & -0.70 & 0.89 & 0.72 & -0.44 & & \\
\hline $\mathrm{pH}$ & 0.72 & 0.84 & 0.76 & 0.69 & 0.66 & 0.69 & 0.77 & -0.84 & -0.87 & 0.59 & -0.74 & \\
\hline Chl $a$ & 0.17 & 0.32 & 0.20 & 0.14 & 0.09 & 0.13 & 0.34 & -0.12 & -0.31 & 0.32 & -0.20 & 0.27 \\
\hline
\end{tabular}
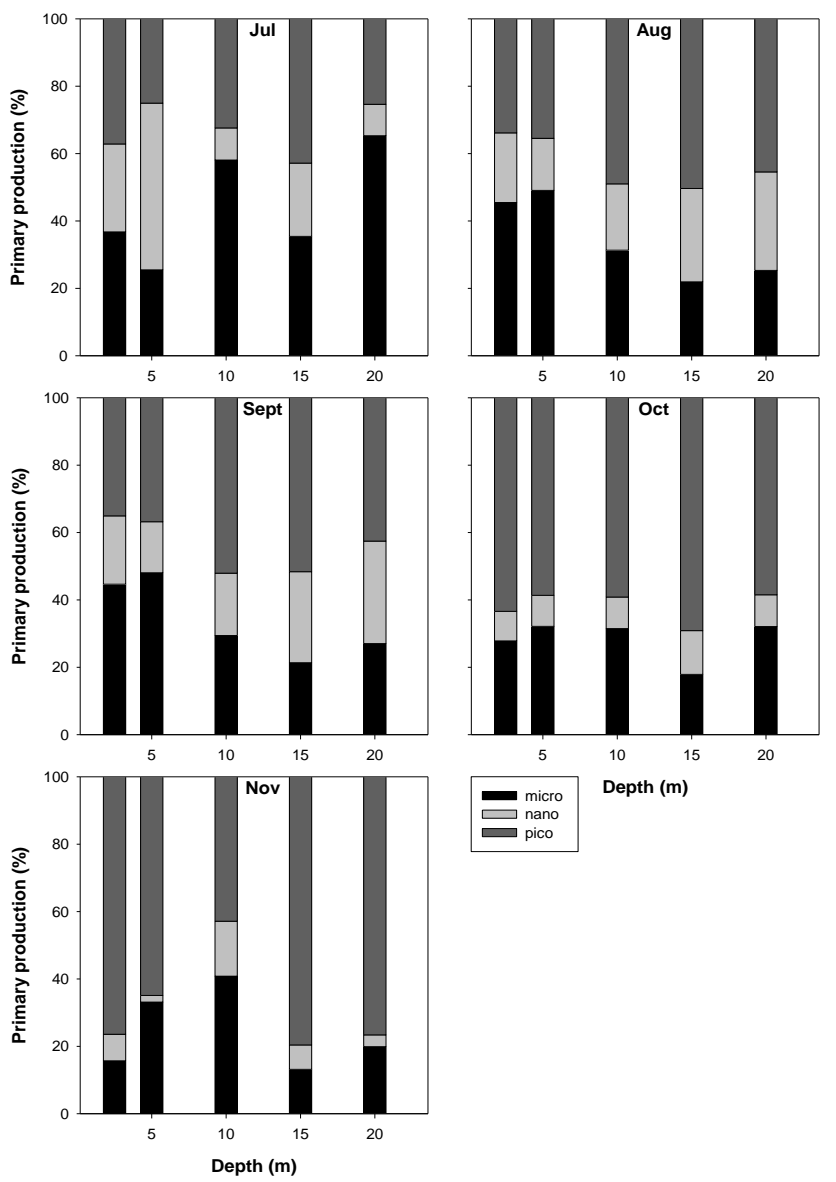

Fig. 5. Fractionated primary production representing the contribution of the various size fractions of the phytoplankton (i.e., the pico-, nano- and microphytoplankton) at the different periods sampled.

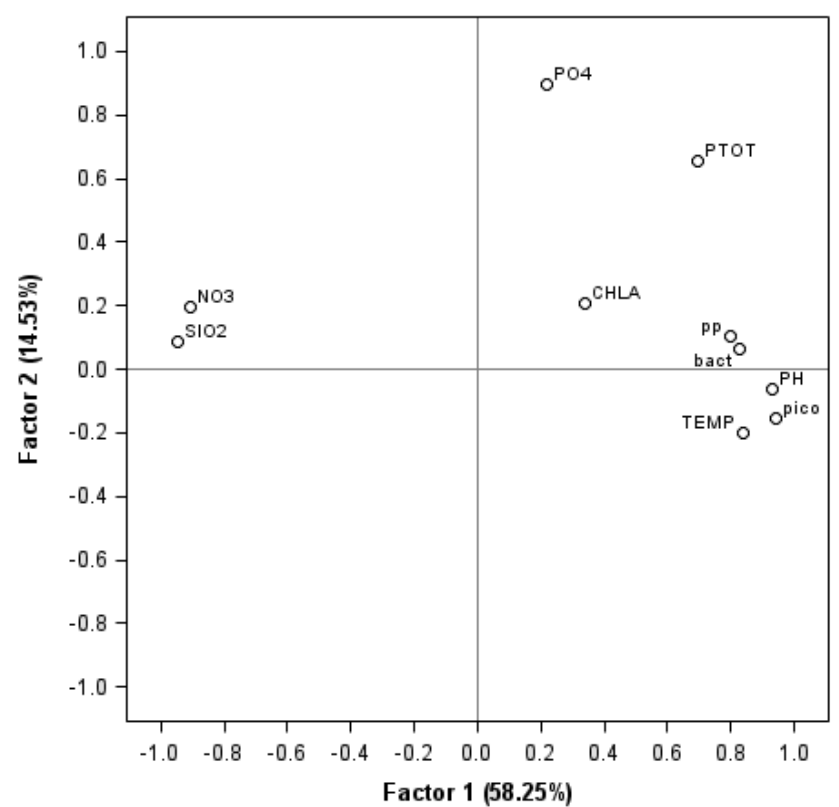

Fig. 6. Principal component regression analysis for bacteria, picocyanobacteria and other phytoplankton with the rest of the environmental variables.

$\mathrm{PO}_{4}(0.89)$ and $\mathrm{P}_{\text {tot }}(0.64)$ were the major components in addition to temperature and $\mathrm{pH}$. For VLPs, bacteria (0.83), picocyanobacteria (0.94) and phytoplankton (0.79) were the significant determinants, with an eigenvalue of 6.41. Temperature, $\mathrm{pH}, \mathrm{NO}_{3}, \mathrm{P}_{\text {tot }}, \mathrm{SiO}_{2}$ and $\mathrm{Chl} a$ explained $65 \%$ of the variability in bacterial abundance (Fig. 6). In the case of picocyanobacteria and other phytoplankton groups, the abovementioned factors accounted for a variability of 90 and $60 \%$, respectively. In the case of VLPs, host abundances (bacteria, picocyanobacteria and potentially all other phytoplanktonic cells) also played an important role in determining the variations observed for viral abundances. Principle component 


\begin{tabular}{|c|c|c|c|}
\hline & Early July & Late July - September & October- November \\
\hline \multicolumn{4}{|l|}{$\begin{array}{l}\text { Proposed } \\
\text { Conceptual } \\
\text { Scheme }\end{array}$} \\
\hline \multicolumn{4}{|l|}{ Abundances $\mathbf{O}$} \\
\hline Picophytoplankton & Moderate & Highest at $10 \mathrm{~m}$ in August & Lowest in November \\
\hline Heterotrophic bacteria & Moderate & Highest in August & Lowest at $30 \mathrm{~m}$ in November \\
\hline Virus & Moderate & Highest in September at $2.5 \mathrm{~m}$ & Lowest in November at $30 \mathrm{~m}$ \\
\hline \multicolumn{4}{|l|}{ Production $\widehat{\wedge}$} \\
\hline Bacteria & Highest & Lowest & Low \\
\hline Virus & Lowest & Moderate & Highest in October \\
\hline Microphytoplankton & Highest & High & Lowest \\
\hline Nanophytoplankton & High & Moderate & Low \\
\hline Picophytoplankton & Moderate & High & Highest in October and November \\
\hline \multirow{4}{*}{$\begin{array}{l}\text { Grazing on bacteria } \rightarrow \\
\text { Grazing on picocyano. } \\
\text { Viral lysis on bacteria } \\
\text { Viral lysis on picocyano. }\end{array}$} & Lowest & High & Low \\
\hline & Low & Highest & Lowest \\
\hline & High, $33 \%$ in July & Moderate & Low \\
\hline & Low & Highest in August & Lowest \\
\hline \multicolumn{4}{|l|}{ Regulation pressure } \\
\hline $\begin{array}{l}\text { Top down control: TD } \\
\text { Bottom up control: } B U\end{array}$ & $\begin{array}{l}\text { Grazing is low on het. bacteria } \\
\text { and picophytoplankton: BU } \\
\text { Bacterial loss due to viral lysis is } \\
\text { high: partly TD }\end{array}$ & $\begin{array}{l}\text { High grazing and viral } \\
\text { lysis on bacteria and } \\
\text { picophytoplankton: TD }\end{array}$ & $\begin{array}{l}\text { Lowest grazing pressure and } \\
\text { viral lysis: } \mathrm{BU}\end{array}$ \\
\hline
\end{tabular}

Fig. 7. Conceptual scenario for the seasonal succession of two major constituents of the microbial food web (the heterotrophic bacteria and the picophytoplankton) in upper layers (0-20 m) of Lake Geneva between July and November 2011.

regression analysis revealed that temperature, $\mathrm{pH}, \mathrm{NO}_{3}, \mathrm{P}_{\text {tot }}$, $\mathrm{SiO}_{2}$ and $\mathrm{Chl} a$ together with host abundances (bacteria, picocyanobacteria and other phytoplankton) contributed $77 \%$ variability in VLP1, 72\% in VLP2 and $78 \%$ in total VLP abundances (not shown).

\section{Discussion}

The main aim of the present study was to shed light on ecological changes occurring in Lake Geneva from early summer to the end of fall. How environmental changes and specific biotic interactions could influence different microbial components (both in terms of abundance and activity) helped us to highlight the importance of some key parameters and viral or grazing pressure in the functioning of the microbial food web of Lake Geneva. In particular, a conceptual model could be proposed for the seasonal succession of key components of the microbial food web structure in the upper lit layer $(0-20 \mathrm{~m})$ of Lake Geneva between July and November 2011 (Fig. 7).

We observed clear variations in the environmental factors such as air and water temperature, light conditions and nutrient concentrations. These variations impacted the abundance of various microbial communities (bacteria, viruses, and picocyanobacteria), which were comparable to what has been reported earlier for Lake Geneva (Duhamel, 2006; Personnic et al., 2009a; Parvathi et al., 2012). The abundances of viruses, bacteria and autotrophic picoplankton changed markedly with months and depths (Table 4). The phytoplankton distribution through the water column was not homogeneous, which could be due to the vertical temperature stratification and light availability. Higher plankton abundance in summer was attributed to higher temperature, availability of light and nutrients that are key determinants for their growth. This is further emphasized by the fact that the transparency was lower during summer compared to fall.

The role of nutrients and their role in controlling the temporal fluctuations in abundance and activity of planktonic algal communities have been considered since the earliest days of phytoplankton ecology (Hutchinson, 1967). The planktonic community structure of an aquatic system largely depends on the lake's trophic state and contribution of picoplankton production to the total autotrophic production, which could vary depending on the nutrient concentrations of the lakes (Stockner and Porter, 1988). These seasonal and vertical variations in total nitrogen and phosphorus have 
Table 4. Results of the two-way ANOVA to test significant differences in the abundance of bacteria, picocyanobacteria, other phytoplankton and VLPs. Degrees of freedom are indicated as df. $\mathrm{S}=$ significant NS = not significant $P<0.01$.

\begin{tabular}{llcrc}
\hline Parameter & Difference & df & $F$ value & Significance \\
\hline Bacteria & months & 5,30 & 31.2 & $\mathrm{~S}$ \\
& depth & 6,30 & 12.3 & $\mathrm{~S}$ \\
\hline \multirow{2}{*}{ Picocyanobacteria } & months & 5,30 & 4.5 & $\mathrm{~S}$ \\
& depth & 6,30 & 14.3 & $\mathrm{~S}$ \\
\hline \multirow{2}{*}{ Other phytoplankton } & months & 5,30 & 7.1 & $\mathrm{~S}$ \\
& depth & 6,30 & 2.3 & $\mathrm{NS}$ \\
\hline \multirow{2}{*}{ VLP1 } & months & 5,30 & 8.7 & $\mathrm{~S}$ \\
& depth & 6,30 & 8.7 & $\mathrm{~S}$ \\
\hline VLP2 & months & 5,30 & 13.7 & $\mathrm{~S}$ \\
& depth & 6,30 & 9.4 & $\mathrm{~S}$ \\
\hline VLP & months & 5,30 & 9.2 & $\mathrm{~S}$ \\
& depth & 6,30 & 9.0 & $\mathrm{~S}$ \\
\hline
\end{tabular}

reflected in the distribution and activity of various planktonic fractions. The relationship between phosphorus concentration and chlorophyll (Dillon and Rigler, 1974) suggests that phosphorus, and at times nitrogen and silicon, are limiting resources. Previous studies in Lake Geneva suggested that $P_{\text {tot }}$ is a critical component determining dynamics of planktonic components in this lacustrine ecosystem (Anneville et al., 2002). The abundance of picocyanobacteria was high during summer months (August-September) when the nutrient concentrations were higher ( $\mathrm{P}_{\text {tot }}$ being $11.0 \pm 4.9 \mu \mathrm{gPL}^{-1}$ in summer) compared to autumn $\left(8.2 \pm 1.9 \mu \mathrm{gPL}^{-1}\right)$. The abundance of planktonic communities positively correlated with $\mathrm{P}_{\text {tot }}$ and negatively correlated with $\mathrm{NO}_{3}$. $\mathrm{P}$ is known as an important component in the dynamics of planktonic communities in lakes (Wetzel, 2000), but the significance of $\mathrm{N}$ in regulating the plankton dynamics especially in Lake Geneva has only been recently reported (Tadonléké et al., 2009). In this regard, the capacity of picocyanobacteria to use $\mathrm{N}$ sources like $\mathrm{NH}_{4} / \mathrm{NO}_{3}$ or switch over from $\mathrm{P}$ or $\mathrm{N}$ subject to the nutrient availability could be considered as an important factor in determining the plankton dynamics in this lake. It is reported that $\mathrm{NO}_{3}$ is taken up by picocyanobacteria in culture when $\mathrm{NH}_{4}$ is depleted (Bird and Wyman, 2003). Even though the abundance was higher in summer, picoplankton production (constituted mainly by picocyanobacteria in Lake Geneva) contributed to a high percentage $(76 \%)$ of the total primary production during autumn (i.e., October and November), suggesting a significant functional role of the "smalls" in Lake Geneva. This could be explained by lower nutrient concentration of total nitrogen $\left(280 \mu \mathrm{g} \mathrm{L}^{-1}\right)$ and total phosphorus $\left(10 \mu \mathrm{g} \mathrm{L}^{-1}\right)$ during the fall period. It is reported that, when nutrients become a limiting factor, autotrophic picoplankton cells strongly compete with the bigger phototrophic organisms (Raven, 1988;
Callieri, 2008). Previous studies reported picocyanobacteria to be the major contributors to total primary production, with their contribution increasing with depth (Platt et al., 1983) due to greater efficiency of their auxiliary pigments (typically phycoerythrin) to utilize the blue-green light (Glover et al., 1985). Long-term changes in phytoplankton composition due to $\mathrm{P}$ loading in Lake Geneva have been found in the past (Anneville et al., 2002). However, to interpret these long-term changes, it is important to gather information on a monthly or seasonal timescale. This study reveals significant seasonal variations in the plankton dynamics which could largely be contributed to temperature, nutrient availability and the wind-induced waves as has previously been reported for peri-Alpine lakes (Vincon-Leite et al., 1989). The results obtained in the present investigation clearly suggest that picocyanobacteria play a crucial role in the trophic status and ecosystem productivity of Lake Geneva as suggested in the past studies for this lake (Duhamel et al., 2006; Personnic et al., 2009a) and elsewhere (Callieri, 2010).

Among the abiotic factors, temperature and $\mathrm{pH}$ were the most influential factors in determining the abundance of bacteria, picocyanobacterial and other phytoplankton which contributed to their monthly variability. Both these parameters were positively correlated and hence play an important role in the structuring of planktonic communities in the lake. Phytoplankton reproduction rates are closely linked to temperature. The maximum rate of cell division doubles for each $10^{\circ} \mathrm{C}$ increase in temperature. The upper limit of growth is therefore determined by temperature (Harris, 1986). Temperature has been reported to be crucial to Prochlorococcus (Olson et al., 1990) and indicated as a dominant factor influencing the seasonal dynamics of both picocyanobacteria and picoeukaryotes in Lake Kinneret (Rushansky et al., 2002). Note that we also found that temperature was among the best predictors of Synechococcus spp. abundance in Lake Bourget (Jacquet et al., 2012). Several phytoplankton species (e.g., the diatom Skeletonema costatum), however, increase their assimilation rates of nutrients at lower temperatures and subsequently increase biomass (Goldman, 1977). The different responses to temperature exhibited by phytoplankton species can lead to a strong seasonal change in species composition and biomass. Most studies of $\mathrm{pH}$ effects on algae have been conducted in freshwater systems where the carbonate buffering system is weaker than in seawater and $\mathrm{pH}$ may fluctuate dramatically (Chen and Durbin, 1994). It can change the distribution of carbon dioxide species and carbon availability, alter the availability of trace metals and essential nutrients, and at extreme $\mathrm{pH}$ levels potentially cause direct physiological effects. It was suggested that, because the solubility and availability of $\mathrm{CO}_{2}$ decrease at high temperature, growth of cyanobacteria with high affinity to $\mathrm{CO}_{2}$ is enhanced (Shapiro, 1990). Variations in viral and bacterial abundances suggested that environmental factors had strong influence on the planktonic communities, as reported in other freshwater systems (Pradeep Ram et al., 2005). Our study 
thus clearly demonstrates that the temperature is a key factor in determining the higher abundance and distribution of phytoplankton in the euphotic layer, which in turn could influence $\mathrm{pH}$.

VLP abundances are linked to the physical and chemical characteristics through their dependence on their heterotrophic and autotrophic hosts. VLP abundances were significantly higher in the top $20 \mathrm{~m}$ (euphotic) layer, and the abundances correlated with bacterial and picocyanobacterial abundances. High VBR in autumn (October and November) and its increase with depth suggested important phagehost interactions. This may also indicate that the impact of viruses on bacteria is more significant in deeper waters than at the surface, as previously observed in this lake and other ecosystems (Weinbauer and Hofle, 1998; Colombet et al., 2006; Personnic et al., 2009a). Such relationships between these groups were clearly confirmed with the measurements of high virus induced mortality on both heterotrophic bacteria and picocyanobacteria. Previous studies have shown a tight coupling of VLP1 and VLP2 with bacterial and picocyanobacterial abundance, respectively (Duhamel et al., 2006; Personnic et al., 2009b). Higher VLP abundance in the upper $20 \mathrm{~m}$ depth could be due to bacterial growth which was stimulated by high temperatures, $\mathrm{pH}$, organic and inorganic nutrients as reported elsewhere (Weinbauer, 2004). The relationship of the viruses with bacteria and picocyanobacteria varied with respect to sampled months, suggesting shifts in the succession of hosts and viruses (Parvathi et al., 2012; Zhong et al., 2013). It is also possible that there were larger initial virioplankton and bacterioplankton populations in the summer months and at the beginning of autumn (Personnic et al., 2009a). A quite similar seasonal pattern was observed for the virioplankton in other temperate lakes, where highest viral abundance occurred in autumn (Bettarel al., 2005; Padeep-Ram et al., 2010). Chl $a$ did not have significant correlation with viruses, suggesting that phytoplankton viruses did not contribute significantly to the total virus pool, and that the positive effect of an increase in chlorophyll $a$ with heterotrophic bacteria is not directly beneficial to viral production. However, we are aware that $\mathrm{Chl} a$ represents only a crude approximation of the algal biomass and thus is probably not the best parameter to use while attempting to identify virus-host relationships (Gasol and Duarte, 2000). It is also possible that picocyanobacteria were the most dominant phytoplanktonic group, thus making them more available for viral attachment (Jacquet et al., 2002). The dynamics of larger phytoplankton and their contribution to primary production showed seasonal variations induced by the environmental factors. High viral production rates (up to $2.6 \times 10^{7}$ particles $\mathrm{mL}^{-1} \mathrm{~h}^{-1}$ ) corroborated this strong viral impact and high viral production coincided indeed with high virus induced bacterial (23\%) and picocyanobacterial (19\%) mortality. Thus, it was not surprising that for both bacteria and picocyanobacteria the loss percentage due to grazing was always lower than viral lysis (as estimated by the dilution method when applicable). These mortality rates were comparable with earlier reports of grazing mortality and viral lysis reported for Lake Geneva and other lakes (Weinbauer and Hofle, 1998; Bettarel et al., 2004; Duhamel et al., 2006; Personnic et al., 2009b). All in all, it was found that viral activity was particularly high in autumn, and covaried with the picoplankton production during the same time period, a result already suggested for these peri-Alpine lakes (Personnic et al., 2009a, b).

All together, results obtained in the context of this study made possible the construction of a conceptual scenario for the seasonal succession of viral and plankton abundance and production as well as the importance of the abiotic and biotic parameters in the upper layers $(0-20 \mathrm{~m})$ of Lake Geneva between July and November 2011 (Fig. 7). The validity of such a model remains to be tested for other years.

\section{Conclusions}

The present study highlighted complex relationships among the microbial components of Lake Geneva where physical, chemical and biotic interactions intervene in the dynamics and activity of the picoplankton size community. The results clearly suggest that the picophytoplanktonic size fraction can be responsible for a significant part of the production of this lake and also show how viral action can be a driving force in the dynamics of the picoplankton (through virus-induced picocyanobacterial and heterotrophic bacterial mortality). Lake Geneva can be considered as a model ecosystem for large and deep temperate lakes, and our analysis, even though limited to only a few months during a single year, strongly highlights the importance of considering the viral component in freshwater plankton ecology.

Acknowledgements. A. Parvathi is grateful to the Director of NIO, Goa, and Scientist-in-charge, NIO, RC, Kochi for their moral support. For A. Parvathi this is NIO contribution number 5536. A. Parvathi was supported by a fellowship provided by INRA. X. Zhong was supported by a fellowship from Région RhôneAlpes. We are thankful to Pascal Perney, Pascal Chifflet and Jean-Christophe Hustache for sampling onboard and technical assistance. We also thank Dr. Pomati, Dr. Hipsey and another anonymous reviewer for the constructive comments they provided to improve this manuscript. Environmental data were obtained from INRA CARRTEL observatory databasis referred to as IS SOERE GLACPE.

Edited by: M. Hipsey 


\section{References}

Anneville, O., Souissi, S., Ibanez, F., Ginot, V., Druart, J. C., and Angeli, N.: Temporal mapping of phytoplankton assemblages in Lake Geneva: Annual and interannual changes in their patterns of succession, Limnol. Oceanogr., 47, 1355-1366, 2002.

Anneville, O., Gammeter, S., and Straile, D.: Phosphorus decrease and climate variability: mediator of synchrony in phytoplankton changes among European peri-alpine lakes, Freshwater Biol., 50, 1731-1746, 2005.

Anneville, O., Molinero, J. C., Souissi, S., Balvay, G., and Gerdeaux D.: Long-term changes in the copepod community of Lake Geneva, J. Plankton Res., 29, 49-59, 2007.

Anneville, A., Beniston, M., Gallina, N., Gillet, C., Jacquet, S., and Perroud, M.: L'empreinte du changement climatique dans le Léman, Arch. Sci., 66, 157-172, 2013.

Auguet, J. C., Barberan, A., and Casamayor, E. O.: Global ecological patterns in uncultured archaea, ISME J., 4, 182-190, 2010.

Azam, F., Fenchel, T., Field, J. G., Gray, J. S., Meyer-Reil, L. A., and Thingstad, F.: The ecological role of watercolumn microbes in the sea, Mar. Ecol.-Prog. Ser., 10, 257-263, 1983.

Berdjeb, L., Pollet, T., Domaizon, I., and Jacquet, S.: Effects of grazers and viruses on bacterial community structure and production in two contrasting trophic lakes, BMC Microb., 11, 1-18, 2011.

Bettarel, Y., Sime-Ngando, T., Amblard, C., and Dolan, J. R.: Viral activity in two contrasting lake ecosystems, Appl. Environ. Microbiol., 70, 2941-2951, 2004.

Bettarel, Y., Sime-Ngando, T., Bouvy, M., Arfi, R., and Amblard, C.: Low consumption of virus-sized particles by heterotrophic nanoflagellates in two lakes of the French Massif Central, Aquat. Microb. Ecol., 39, 205-209, 2005.

Binder, B. J.: Reconsidering the relationship between virallyinduced bacterial mortality and frequency of infected cells, Aquat. Microb. Ecol., 18, 207-215, 1999.

Bird, C. and Wyman, M.: Nitrate/nitrite assimilation system of the marine cyanobacterium Synechococcus sp. strain WH8103: Effect of nitrogen source and availability on gene expression, Appl. Environ. Microbiol., 69, 7009-7018, 2003.

Breitbart, M.: Marine viruses: truth or dare, Ann. Rev. Mar. Sci., 4, 425-448, 2012.

Callieri, C.: Picophytoplankton in freshwater ecosystems: the importance of small-sized phototrophs, Freshwater Rev., 1, 1-28, 2008.

Callieri, C.: Single cells and microcolonies of freshwater picocyanobacteria: a common ecology, J. Limnol., 69, 257-277, 2010.

Callieri, C. and Stockner, J. G.: Freshwater autotrophic picoplankton: a review, J. Limnol., 61, 1-14, 2002.

Chen, C. Y. and Durbin, E. G.: Effects of $\mathrm{pH}$ on the growth and carbon uptake of marine phytoplankton, Mar. Ecol.-Prog. Ser., 109, 83-94, 1994.

Clasen, J. L., Brigden, S. M., Payet, J. P., and Suttle, C. A.: Evidence that viral abundance across oceans and lakes is driven by different biological factors, Freshwater Biol., 53, 1090-1100, 2008.

Colombet, J., Sime-Ngando, T., Cauchie, H. M., Fonty, G., Hoffmann, L., and Demeure, G.: Depth-related gradients of viral activity in Lake Pavin, Appl. Environ. Microbiol., 72 , 4440-4445, 2006.
Dilon, P. J. and Rigler, F. H.: The phosphorus-chlorophyll relationship in lakes, Limnol. Oceanogr. 19, 767-773, 1974.

Duhamel, S. and Jacquet, S.: Flow cytometric analysis of bacteriaand virus-like particles in lake sediments, J. Microbiol. Meth., 64, 316-322, 2006.

Duhamel, S., Zeman, F., and Thierry, M.: A dual-labeling method for the simultaneous measurement of dissolved inorganic carbon and phosphate uptake by marine planktonic species, Limnol. Oceanogr. Meth., 4, 416-425, 2005.

Duhamel, S., Domaizon, I., Personnic, S., and Jacquet, S.: Assessing the microbial community dynamics and the role of viruses as bacterial mortality agents in Lake Geneva, J. Water Sci., 19, 115-126, 2006.

Evans, C., Archer, S. D., Jacquet, S., and Wilson, W. H.: Direct estimates of the contribution of viral lysis and microzooplankton grazing to the decline of a Micromonas spp. population, Aquat. Microb. Ecol., 30, 207-219, 2003.

Fuhrman, J. A. and Noble, R. T.: Viruses and protists cause similar bacterial mortality in coastal seawater, Limnol. Oceanogr., 40, 1236-1242, 1995.

Gasol, J. M. and Duarte, C. M.: Comparative analyses in aquatic microbial ecology: how far do they go?, FEMS Microbiol. Ecol., 31, 99-106, 2000.

Glover, H. E., Phinney, D. A., and Yentsch, C. S.: Photosynthetic characteristics of picoplankton compared with those of higher phytoplankton populations in various water masses in the Gulf of Maine, Biol. Oceanogr., 3, 223-248, 1985.

Goldman, J. C.: Temperature effects on phytoplankton growth in continuous culture, Limnol. Ocean., 22, 932-935, 1977.

Harris, G. P.: Phytoplankton ecology: Structure, function, and fluctuationm Chapman and Hall, London, UK, 1986.

Hutchinson, G. E.: A treatise on limnology, Vol. 2, Wiley, New York, 1967.

Ishiguro, N. and Balvay, G.: L'écoulement des eaux du Rhône dans le lac Léman, Archs Sci. Genève, 56, 117-126, 2003.

Jacquet, S., Havskum, H., Thingstad, F. T., and Vaulot, D.: Effect of inorganic and organic nutrient addition on a coastal microbial community (Isefjord, Denmark), Mar. Ecol.-Prog. Ser., 228, 314, 2002.

Jacquet, S., Miki, T., Noble, R., Peduzzi, P., and Wilhelm, S. Viruses in aquatic ecosystems: important advancements of the last 20 years and prospects for the future in microbial oceanography and limnology, Adv. Oceanogr. Limnol., 1, 71-101, 2010.

Jacquet, S., Barbet, D., Cachera, S., Caudron, A., Colon, M., Girel, C., Guillard, J., Hébert, A., Kerrien, F., Laine, L., Lazzarotto, J., Moille, J.-P., Paolini, G., Perga, M.-E., Perney, P., and Rimet, F. Suivi environnemental des eaux du lac du Bourget pour l'année 2011, Rapport INRA-CISALB-CALB, p. 220, 2012.

Jacquet, S., Dorigo, U., and Personnic, S.: A few tests prior to flow cytometry and epifluorescence analyses of freshwater bacterioand virioplankton communities, in: Flow Cytometry: Principles, Methodology and Applications, Chapter 1, Related Nova publication, Nova Publishers Inc., New York, 1-30, 2013.

Jugnia, L. B., Tadonléké, R. D., Sime-Ngando, T., Devaux, J., and Andrivon, C.: Bacterial population dynamics, production, and heterotrophic activity in a recently formed reservoir, Can. J. Microbiol., 45, 747-753, 1999. 
Kimmance, S. A., Wilson, W. H., and Archer, S. D.: Modified dilution technique to estimate viral versus grazing mortality of phytoplankton: limitations associated with method sensitivity in natural waters, Aquat. Microb. Ecol., 49, 207-222, 2007.

Lazzarotto, J. and Klein, A.: Evolution physico-chimique des eaux du Léman, rapport CIPEL pour l'année 2011, 26-50, 2012.

Lemmin, U., Fer, I., and Perrinjaquet, C.: Courantologie lémanique: le refroidissement hivernal, in: Découvrir le Léman 100 ans après François-Alphonse Forel, Actes du colloque pluridisciplinaire, Editions Slatkine, Nyon-Genève, 53-67, 1999.

Li, W. K. W., Subba-Rao, D. V., Harrison, W. G., Smith, J. C., Cullen, J. J., Irwin, B., and Platt, T.: Autotrophic picoplankton in the tropical ocean, Science, 219, 292-295, 1983.

Maranger, R. and Bird, D. F.: Viral abundance in aquatic systems: a comparison between marine and fresh waters, Mar. Ecol.-Prog. Ser., 121, 217-226, 1995.

Olson, R. J., Chisholm, S. W., Zettler, E. R., Altabet, M., and Dusenberry, J.: Spatial and temporal distributions of prochlorophyte picoplankton in the North Atlantic ocean, Deep-Sea Res., 37, 1033-1051, 1990.

Parvathi, A., Zhong, X., and Jacquet, S.: Dynamics of various viral groups infecting autotrophic plankton in Lake Geneva, Adv. Ocean. Limnol., 3, 171-191, 2012.

Pelletier, J. P. and Orand, A.: Appareil de prelevement d'un echantillon dans un fluide, INRA Patent number 1978 76.08579, 1978.

Personnic, S., Domaizon, I., Dorigo, U., Berdjeb, L., and Jacquet, S.: Seasonal and spatial variability of virio-, bacterio, and picophytoplanktonic abundances in three peri-alpine lakes, Hydrobiologia, 627, 99-116, 2009a.

Personnic, S., Domaizon, I., Sime-Ngando, T., and Jacquet, S.: Seasonal variations of microbial abundances and of virusvs. flagellate- induced mortality of picophytoplankton in some peri-alpine lakes, J. Plankton Res., 31, 1161-1177, 2009b.

Platt, T., Subba-Rao, D. V., and Irwin, B.: Photosynthesis of picoplankton in the oligotrophic ocean, Nature, 300, 701-704, 1983.

Pradeep Ram, A. S., Boucher, D., Sime-Ngando, T., Debroas, D., and Romagoux, J. C.: Phage bacteriolysis, protistan bacterivory, and bacterial production in a freshwater reservoir: coupling with temperature, Microb. Ecol., 50, 64-72, 2005.

Pradeep Ram, A. S., Arnous, B., Danger, M., Carrias, J. F., Lacroix, G., and Sime-Ngando, T.: High and differential viral infection rates within bacterial 'morphopopulations' in a shallow sand pit lake (Lac de Creteil, France), FEMS Microbiol. Ecol., 74, 83-92, 2010.

Raven, J. A.: The twelfth Tansley Lecture: Small is beautiful: The picophytoplankton, Funct. Ecol., 12, 503-513, 1998.

Rushansky, N. M., Berman, T., Berner T., Yacobi, Y. Z., and Dubinsky, A. Z.: Physiological characteristics of picophytoplankton, isolated from Lake Kinneret: responses to light and temperature, J. Plankton Res., 24, 1173-1183, 2002.

Sarmiento, J. L. and Gruber, N.: Ocean Biogeochemical Dynamics, Princeton University Press, Princeton, New Jersey, USA, 2006.

Shapiro, J: Current beliefs regarding dominance by blue-greens: the case for the importance of $\mathrm{CO}_{2}$ and $\mathrm{pH}$, Verhand. Int. Ver. Theor. Angew. Limnol., 24, 38-54, 1990.
Sime-Ngando, T., Mignot, J. P., Amblard, C., Bourdier, G., Desvilettes, C., and Quiblier-Lloberas, C.: Charactérisation des particules virales planctoniques dans un lac du Massif Central Français: Aspects méthodologiques et premiers résultats, Annales de Limnology - International Journal of Limnology, 32, 259-263, 1996.

Stockner, J. G. and Porter, K. G.: Microbial food webs in fresh water planktonic ecosystems, in: Complex interactions in lake communities, edited by: Carpenter, S. R., Springer-Verlag, New York, 69-83, 1988.

Suttle, C. A.: Viruses in the sea, Nature, 437, 356-361, 2005.

Tadonléké, D. R.: Evidence of warming effects on phytoplankton productivity rates and their dependence on eutrophication status, Limnol. Oceanogr., 55, 973-982, 2010.

Tadonléké, D. R., Planas, D., and Lucotte, M.: Microbial food web in boreal humic lakes and reservoirs: ciliates as a major factor related to the dynamics of the most active bacteria, Microb. Ecol., 49, 325-341, 2005.

Tadonléké, D. R., Lazzarotto, J., Anneville, O., and Druart, J.-C.: Phytoplankton productivity increased in Lake Geneva despite phosphorus loading reduction, J. Plankton Res., 31, 1179-1194, 2009.

Thomas, R., Berdjeb, L., Sime Ngando, T., and Jacquet, S.: Viral abundance, production, decay rates and life strategies (lysogeny versus lysis) in Lake Bourget (France), Environ. Microbiol., 13, 616-630, 2011.

Utermöhl, H.: Neue Wege in der quantitativen Erfassung des Planktons (mit besonderer Berücksichtigung des Ultraplanktons), Verh. Int. Ver. Theor. Angew. Limnol., 5, 567-596, 1931.

Vincon-Leite, B., Mouchel, J. M., and Tassin, B.: Modelisation de l'evolution thermique saisonniere du lac du Bourget (Savoie, France), Rev. Des. Sci., 2, 483-510, 1989.

Weinbauer, M. G.: Ecology of prokaryotic viruses, FEMS Microbiol. Rev., 28, 127-181, 2004.

Weinbauer, M. G. and HÖfle, M. G.: Significance of viral lysis and flagellate grazing as factors controlling bacterioplankton production in a eutrophic lake, Appl. Environ. Microbiol., 64, 431-438, 1998.

Weinbauer, M. G. and Suttle, C. A.: Comparison of epi-fluorescence and transmission electron microscopy for counting viruses in natural marine waters, Aquat. Microb. Ecol., 13, 225-232, 1997.

Weinbauer, M. G., Winter, C., and Hofle, M.: Reconsidering transmission electron microscopy based estimates of viral infection of bacterioplankton using conversion factors derived from natural communities, Aquat. Microb. Ecol., 27, 103-110, 2002.

Wetzel, R. G.: Limnology, lake and river ecosystems, Academic Press, 3rd Edn., London, UK, p. 1006, 2000.

Whitman, W. B., Coleman, D. C., and Wiebe, W. J.: Prokaryotes: the unseen majority, P. Natl. Acad. Sci., 95, 6578-6583, 1998.

Wilhelm, S. W., Brigden, S. M., and Suttle, C. A.: A dilution technique for the direct measurement of viral production: a comparison in stratified and tidally mixed coastal waters, Microb. Ecol., 43, 168-173, 2002.

Worden, A. Z. and Not, F.: Ecology and Diversity of Picoeukaryotes, in: Book Chapter in: Microbial Ecology of the Ocean, 2nd Edn., edited by: Kirchman, D., Wiley, San Francisco, 2008. 
Worden, A. Z., Nolan, J. K., and Palenik, B.: Assessing the dynamics and ecology of marine picophytoplankton: the importance of the eukaryotic component, Limnol. Oceanogr., 49, 168-179, 2004.
Zhong, X., Berdjeb, L., and Jacquet, S.: Temporal dynamics and structure of picocyanobacteria and cyanomyoviruses in two large and deep peri-alpine lakes, FEMS Microbiol. Ecol., 86, 312-326, 2013. 